\title{
STUDI DAN ANALISIS PENYELESAIAN ISU-ISU INTOLERANSI KEAGAMAAN DI SUMATERA BARAT TAHUN 2014-2015
}

\author{
Silfia Hanani \\ IAINBukittinggi,Silfia_hanani@yahoo.com \\ Nofrianti Putri Utami \\ LAIN Bukittinggi,nofriantiutami27@gmail.com
}

Diterima: 23 Juli 2019

Direvisi : 19 November 2019

Diterbitkan: 25 Desember 2019

\begin{abstract}
Religious intolerance in West Sumatra in 2014-2015 experienced an increase which was affected by the rejection of facilities that would be built by investors of different religions with the majority of religious communities. Religious intolerance is an indicator of the low attitude of religious tolerance in society. The phenomenon of racism and theological nuances in Indonesia seems to strengthen the suspicion that religion is the cause of conflict, triggers of violence, and a variety of behaviors that sometimes generate not only hatred, but also hostility, and fierce warfare among humans. However, the case does not cause conflict diversity in this region because of the solutions made for each of these issues. At this time, religious themes have been developed by the community, where people are not easy to accept the religion of Islam that has just been developed by the stranded Arabian sword. After Islam became the official religion of the Minangkabau people in West Sumatra, in general, in West Sumatra, the issue of faith became the part that received attention; the effect of religion meant how to respond to the arrival or emergence of movements outside of the majority religion. This paper describes the solutions made to reduce these issues so as not to cause religious conflict.
\end{abstract}

Keywords: Tolerance, Religious Intolerance, Religious Conflict.

\begin{abstract}
Abstrak
Intoleransi beragama di Sumatera Barat pada tahun 2014-2015 mengalami peningkatan yang dipengarubi oleh penilakan-penolakan fasilitas yang akan dibangun oleh investor yang berbeda agama dengan mayoritas agama masyarakat. Intoleransi beragama ini sebagai indikator rendahnya sikap toleransi beragama masyarakat. Fenomena intoleransi dan konflik bernuansa agama di Indonesia seakan menguatkan kecurigaan babwa agama sebagai penyebab konflik, pemicu tindak kekerasan, dan beragam perilaku yang terkadang bukan sekadar melabirkan kebencian, tapi juga permusuban, dan peperangan dabsyat di antara sesama manusia Walaupun demikian, kasus tersebut tidak menimbulkan konflik keberagamaan di wilayah ini, karena adanya solusi yang dilakukan untuk setiap adanya isu-isu tersebut. Pada masa ini sudah isu-isu agama sudah dibangun oleh masyarakat, dimana masyarakat tidak mudah menerima agama Islam yang baru saja dikembangkan oleh pedangang Arab yang terdampar itu. Setelab Islam menjadi agama resmi masyarakat Minangkabau di Sumbar, maka pada umumnya di Sumatera Barat isu agama menjadi bahagian yang mendapatkan perbatian, isu agama artinya adalab bagaimana respon yang muncul terhadap kedatangan atau munculnya gerakan diluar dari agama mayoritas. Tulisan ini, menjelaskan tentang solusi-solusi yang dilakukan untuk meredam isu-isu tersebut sehingga tidak menimbulkan konflike keagamaan tersebut.
\end{abstract}

Kata Kunci: Toleransi, Intoleransi Keagamaan, Konflik Keagmaan. 


\section{PENDAHULUAN}

Minangkabau pada mulanya didatangi oleh seorang pedangan Arab dengan cara tidak sengaja, mereka terdampar di sebuah selat di Pantai Pariaman pada tauun 580H/1184-1185 M. Semula pedagang ini hendak melanjutkan perdangangannya ke Timur, namun terdampar di Pulau Perca nama dari wilayah ini dahulunya. Pedangan Arab ini kemudian diselamatkan oleh orang kampung dan tinggal bersama dengan orang kampung kemudian menikah dengan anak kepala nagari. Pedagang Arab ini bernama Saidi Abdullah. Saidi Abdullah memperkenalkan Islam ke orang yang menyelamatkannya yang pada saat itu beragama Budha dan Hindu ${ }^{1}$

Pada masa ini sudah isu-isu agama sudah dibangun oleh masyarakat, dimana masyarakat tidak mudah menerima agama Islam yang baru saja dikembangkan oleh pedangang Arab yang terdampar itu. Pada saat itu agama Budha dan Hindu masih kuat dan mayoriti dipraktekkan oleh masyarakat setempat. Elite-elit adat dan agama ketika itu tidak mudah menerima ajaran yang diperkenalkan oleh pedagang Arab yang terdampar ini. Tidak menerima ajaran baru yang didengar oleh masyarakat setempat. Fenomena intoleransi dan konflik bernuansa agama di Indonesia seakan menguatkan kecurigaan bahwa agama sebagai penyebab konflik, pemicu tindak kekerasan, dan beragam perilaku yang terkadang bukan sekadar melahirkan kebencian, tapi juga permusuhan, dan peperangan dahsyat di antara sesama manusia. $^{2}$

Isu-isu agama ketika itu sudah terlihat, bagaimana elite adat menentang kedatangan agama yang dikembangkan oleh pedagang Arab. Ketika itu orang kampung sudah

1 Imam Maulana Abdul Munaf Al-Amin, Mubalighul Islam, (Padang: Bagian Urusan Kebudayaan Sumatera Barat, 1883), 57

2 Enjang Muhaemin, and Irfan Sanusi, "Intoleransi Keagamaan dalam Framing Surat Kabar Kompas" Communicatus: Jurnal Ilmu Komunikasi, 3.1 (2019), 19 nyaman dengan agama nenek moyangnya, mereka sudah nyaman dengan praktek-praktek agama yang diterima oleh nenek moyangnya. Untuk itu, pengembangan agama Islam oleh pedagang Arab tersebut tidak mudah dilakukannya tetapi melalui proses yang panjang melalui pendekatan-pendekatan elit adat bahkan melalui pernikahan. Setelah itu baru dilakukan pengenalan terhadap agama Islam di wilayah diberinama Pulau Perca ini, sebelum bernama Minangkabau. Elilte ada ketika itu beragama Budha-Hindu tidak mudah menerima begitu saja ajaran-ajaran baru yang datang ketengah-tengah mereka. Pada tahap awal ini kedatangan Islam tidak berhasil menjadi agama baru bagi masyarakat, sehingga sepeninggal Saidi Abdullah praktek-praktek Hindu dan Budha itu berkembang kembali dan praktek agama Islam memudar ${ }^{3}$

Cukup lama terjadi kekosongan Islam di Pulau Perca atau Minangkabau ini, baru pada tahun 1037H/1627-1628M datang lagi seorang ulama dari Madinah yang hendak mengembangkan Islam ke Gujarat di India namun diperjalanan kapalnya karam pula, akhirnya terdampar sampai di Nagari Tiku. Menurut catatan Amin ulama itu bernama Abdullah Arif masyarakat di Pantai Barat Pariaman menyebutnya dengan Ungku Madinah. Abdullah Arif tersebut membawa sebuah kita dari gurunya nama kitab itu adalah Taupah, kitab ini menjadi pegangan tarikat Syatariah Burhanuddin. ${ }^{4}$

Dari Pantai Tiku ulama ini berjalan hingga betemu sebuah perkampungan yang sekarang bernama Tapakis. Di daerah ini ulama itu dibantu oleh masyarakat sehingga bisa menetap dan tinggal bersaama dengan penduduk, bahkan masyarakat membantu mendirikan tempat tinggal untuknya, kemudian tempat tinggalnya ini dikenal dengan surau. Tempat tinggal ulama ini kemudian diabadikan sampai sekarang dengan nama

\footnotetext{
3 Imam Maulana Abdul Munaf Al-Amin, Mubaligbul Islam, 58

${ }^{4}$ Ibid., 61
} 
Surau Madinab karena Abdullah Arif itu berasal dari Madinah dan dijuluki oleh masyarakat setempat pada waktu itu dengan Ungku Madinah.

Pada masa priode ke dua ini, isu agama kembali menjadi bahagian penting dikalangan masyarakat Minangkabau yang sudah terbiasa dan mendalam dengan ajaran Budha dan Hindu tersebut. Perlawanan-perlawanan elite juga berdatangan, namun dapat diatasi oleh Ungku Madinah itu, karena dia mengembangkan Islam dengan pendekatanpendekatan elit dan mendirikan basis pendidikan agama Islam itu sendiri melalui lembaga surau sehingga lama kelamaan isu agama bisa redam dan bahkan Ungku Madinah mendapatkan tempat di dalam masyarakat sehingga Islam berkembang serta diterima menjadi gama baru dalam masyarakat Minangkabau.

Pada tahap Islam kedua ini, isu-isu agama sudah mulai tidak menjadi perhatian dikalangan masyarakat Minangkabau, sehingga Islam dapat berkembang dan diterima menjadi salah satu bahagian ajaran agama di kalangan masyarakat Minangkabau ketika itu. Bahkan agama Islam sudah berkembang di sepanjang pesisir Pariaman itu, tidak hanya di Tiku saja tetapi juga sudah berkembang ke Tanjung Medan dan wilayah-wilayah sekitarnya.

Akhirnya Burhanuddin berguru kepada Abdurrauf Singkel selama 30 tahun dan kemudian pulang ke Minangkabau pada tahun 1070H/1660M. Burhanuddin memilih pulang ke pesisir pantai Pariaman yang dekat dengan tempat surau Ungku Madinah. Burhanuddin menempati kampung Tanjung Medan, di daerah ini masyarakat memberinya sebuah surau sebagai tempat tinggal dan mengajarkan mengaji.

Surau Burhanuddin kemudian berkembang dan banyak didatango oleh anak muda dari berbagai daerah, sehingga Islam semakin mengakar di daerah pesisir di Minangkabau. Murid-murid Burhanuddin yang datang dari beberapa daerah ini kemudian pulang ke kampung halamannya mendirikan surau pula sebagai tempat untuk mengembangkan ilmunya, sehingga ketika itu seorang ulama pasti memiliki surau untuk menjalankan perannya sebagai guru dari umat elite agama di tengah-tengah masyarakat. Dengan kondisi yang demikian Islam cepat berkembang dan diterima oleh masyarakat di daerah ini.

Perkembangan yang demikian itu bukan berarti tidak mendapatkan tantangan dari kelompok-kelompok mayoritas beragama Budha-Hindu ketika itu, malahan juga dari kalangan elite-elite adat dan para tokoh-tokoh mistik ketika itu. Amin menceritakan kedatangan Islam di wilayah Pariaman ketika itu dapat tantangan besar daripada elit adat di Pariaman, terutama dikalangan "mistikus" yang berempat, yakni tokoh-tokoh yang ditakuti oleh masyarakat karena kekuatan misktik yang dimilikinya, orang yang berempat ini adalah, Kalit-Kalit Jantan, Gagar Tangan Padang, Sijan Panas dan Siwan. Dari segi nama saja mereka sangat menakutkan apalagi dengan tindakannya. Orang kampung takut kepadanya karena mistik yang dimilikinya. ${ }^{5}$

Walaupun Islam mendapat perlawanan-perlawanan ketika itu, isu-isu agama menjadi sebagai sumber konflik pada masa itu namun Islam sebagai agama minoritas secara berlahan-lahan bisa diterima dan berkembang ditengah-tengah masyarakat Minangkabau. Akhirnya menjadi agama mayoritas yang dideklerasikan di dalam sebuah pertemuan antara orang adat dan agama di Bukit Marapalam pada tahun 1668M. Deklerasi itu menghasilkan statemen adaik basandi syarak, syarak basandi kitabullak.

Islam menjadi agama mayoritas, sehingga pusat kerajaan Pagariyung mengukuti aturan mayoritas ini sebagaimana dapat dilihat dari perubahan struktur pemerintahan di pusat kerajaan. Lahirnya dua raja pembantu yakni raja adat dan ibadat, kemudian Raja alam 
Minangkabau ketika itu Sutan Alif memeluk agama Islam. Kondisi ini menjadikan Islam menggantikan agama mayoritas Budha-Hindu ketika itu.

Namun, pengamalan Islam masyarakat belum pernah selesai praktik-praktik masa lalu masih saja terjadi dan diamalkan. Praktikpraktik lokal ini kemudian secara radikal ditumpas oleh kedatangan gerakan Wahabi yang berkembang di dunia Islam dan gerakan itu dibawa ke Minangkabau oleh tiga orang haji pada tahun 1802, tiga haji itu adalah Haji Miskin dari Pandai Sikat (Luhak Agam), Haji Abdur Rahman dari Piabang (Luhak Lima Puluh) dan Haji Muhammad Arief dari Sumanik (Luhak Tanah Datar). Kemudian gerakan tiga haji ini dibantu oleh orang-orang yang terpengaruh dari tiga haji ini, jumlah mereka delapan orang makanya mereka disebut dengan harimau nan salapan. Delapan orang yang bergabung dengan gerakan itu adalah, Tuanku Nan Renceh di Kamang, Tuanku di Kubu Sanang, Tuanku di Ladang Lawas, Tuanku di Koto di Padang Luar, Tuanku di Galung, Tuanku di Koto Ambalau dan Tuanku di Lubuk Aur.

Kelompok ini melakukan radikalisme dalam menyebarkan dan membersifkan praktik-prarktik budaya lokal dikalangan masyarakat Minangkabau pada masa itu, bahkan mereka tidak segan-segan melakukan pembunuhan atau pembakaran, gerakan pemurnian. Gerakan Wahabi ini melahirkan gerakan Paderi yang kemudian berorientasi melawan ketidakadilan dan kesemena-menaan kolonial Belanda. Gerakan Paderi ini kemudian dipimpin oleh Tuanku Imam Bonjol. ${ }^{6}$

Pada dasarnya, isus-isu agama itu dalam masyarakat yang berinteraksi dengan dunia luar ternyata sudah menjadi catatancatatan sejarah tersendiri. Di Minangkabau yang kemudian menjadi sebahagian besar mendiami daerah wilayah administrasi

${ }^{6}$ Djokosurjo, dkk., Agama dan Perubahan Sosial, Studi Antara Hubungan Islam, Masyarakat dan Struktur Sosial Politik Indonesia, (Yogyakarta: LPKSM, 2001), 171.
Sumatera Barat, isu agama itu sudah berkembang semenjak Islam datang secara tidak sengaja ke daerah ini. Isu-isu agama itu dilalatar belakangi oleh isu mayoritas dan minoritas kemudian bergeser pada isu pemurnian yang bergerakan secara radikal. Agaknya, isu pemurnian ini memberikan kesan dan lebih mempertegas isu agama itu bahagian yang tidak bisa ditinggalkan oleh orang Minangkabau yang di Sumatera Barat ini.

Dari catatan sejarah ini, maka dapat pula dilihat bahwa isu-isu agama ada yang berkontribusi terhadap konflik yang mengacu kepada pertumpahan darah atau kekerasan yang menelan korban material dan nyawa. Dari perkembangan dan proses interaksi agama di daerah ini maka dapat dijelaskan isu-isu agama yang pernah berkembang di daerah ini, sebagaimana dapat dilihat pada tabel berikut:

Tabel 1

Bentuk Isu Agama Di Minangkabau Sebahagian Besar di Sumatera Barat

\begin{tabular}{|c|c|c|c|c|}
\hline \multirow[t]{2}{*}{ Priode } & \multicolumn{2}{|c|}{ Bentuk Isu Agama } & \multirow{2}{*}{$\begin{array}{l}\text { Bentuk } \\
\text { Gerakan }\end{array}$} & \multirow[t]{2}{*}{ Tokoh } \\
\hline & Mayoritas & Minorias & & \\
\hline $\begin{array}{l}\text { Awal } \\
1184 / 11 \\
85\end{array}$ & $\begin{array}{l}\text { Budha- } \\
\text { Hindu }\end{array}$ & Islam & Penolakan & $\begin{array}{l}\text { Adat dan } \\
\text { Mistikus }\end{array}$ \\
\hline $\begin{array}{l}\text { Kedua } \\
1627 / 16 \\
28\end{array}$ & $\begin{array}{l}\text { Budha- } \\
\text { Hindu }\end{array}$ & Islam & Penolakan & $\begin{array}{l}\text { Adat dan } \\
\text { Mistikus }\end{array}$ \\
\hline $\begin{array}{l}\text { Ketiga } \\
1660\end{array}$ & $\begin{array}{l}\text { Budha- } \\
\text { Hindu }\end{array}$ & Islam & Konflik & $\begin{array}{l}\text { Adat- } \\
\text { Mistikus } \\
\text { dan elite } \\
\text { agama }\end{array}$ \\
\hline $\begin{array}{l}\text { Ketiga } \\
\text { Era } \\
\text { Wahabi } \\
\text { ah } 1802\end{array}$ & $\begin{array}{l}\text { Islam } \\
\text { Lokalitas }\end{array}$ & $\begin{array}{l}\text { Islam } \\
\text { Pemurnian }\end{array}$ & Pemurnian & $\begin{array}{l}\text { Pemeluk } \\
\text { agama dan } \\
\text { Tokoh } \\
\text { Wahabiah }\end{array}$ \\
\hline $\begin{array}{l}\text { Paderi } \\
1821- \\
1837\end{array}$ & Islam & $\begin{array}{l}\text { Penolakan } \\
\text { Kolinali }\end{array}$ & Perang & $\begin{array}{l}\text { Imam } \\
\text { Bonjol }\end{array}$ \\
\hline
\end{tabular}

Sumber: Diolah dari beberapa literature

Setelah Islam menjadi agama resmi masyarakat Minangkabau di Sumbar, maka pada umumnya di Sumatera Barat isu agama menjadi bahagian yang mendapatkan perhatian, isu agama artinya adalah bagaimana respon yang muncul terhadap kedatangan atau munculnya gerakan diluar dari agama 
mayoritas. Penduduk Sumatera Barat yang dominan beretnis Minangkabau dan beragama totalitas Islam, maka penerimaan terhadap gerakan diluar dari Islam sangat sensitif, bahkan bisa berujung dengan konflik, minimal dalam bentuk intoleransi beragama dengan bentuk penolakan-penilakan terhadap simbol dan kehadiran proyek pengembangan yang dilakukan oleh umat beragam selain dari Islam.

Isu kristenisasi mendominasi jika dibandingkan dengan isu-isu agama lainnya. Tentu hal ini tidak terlepas daripada jumlah penganut agama ini lebih banyak dibandingkan dengan jumlah penganut agama lainnya selain daripada Islam dan tersebar diseluruh wilayah kota dan kabupaten. Data jumlah penganut agama ini dapat dilihat sebagai berikut.

Tabel 2

Jumlah Penduduk Sumatera Barat Berdasarkan Agama

\begin{tabular}{|c|l|l|}
\hline No & \multicolumn{1}{|c|}{ Agama } & \multicolumn{1}{c|}{ Jumlah Penganut } \\
\hline 1 & Islam & 4.721 .924 \\
\hline 2 & Kristen & 69.253 \\
\hline 3 & Khatolik & 40.428 \\
\hline 4 & Hindu & 234 \\
\hline 5 & Budha & 3.419 \\
\hline 6 & Konghucu & 70 \\
\hline 7 & Lain-lain & 11.581 \\
\hline \multicolumn{2}{|c|}{ Jumlah } & 4.846 .908 \\
\hline
\end{tabular}

Sumber BPS Sumbar 2010

Dari data di atas dapat diketahui, bahwa diantara umat beragam selain dari pada Islam di Sumatera Barat agama Nasrani paling banyak dibandingkan dengan yang lain. Keberadaan penganut agama ini tersebar diberbagai wilayah kota dan kabupaten yang ada di Sumatera Barat, sebagaimana dapat dilihat dari table berikut ini:

Dari 7 Kota dan 12 Kabupaten di Sumatera Barat, ternyata jumlah beragama Nasrani (Khatolik dan Protestan) banyak di Kabupaten Kepulauan Mentawai. Di Kabupaten ini Islam dan agama selain daripada beragama Nasrani. Dilihat dari jumlah ini ternyata agama ini juga melakukan gerakangerakan atas nama keagamaan yang lebih banyak pula dibandingkan dengan agama yang lainnya. Kegiatan-kegiatan yang dilakukan oleh kelompok ini sering menjadi isu keagamaan. Berbeda dengan agama-agama yang jumlahnya sedikit, sering tidak menimbulkan isu karena tidak banyak melakukan kegiatan keagamaan. Misalnya kelompok penganut agama Konghuchu misalnya, tidak banyak melahirkan isu keagamaan.

Kelompok Konghucu menjadikan bahasa lokal sebagai media untuk bernegosiasi dengan masyarakat dimana keberadaannya. Dengan kelompok agama ini, kelompokkelompok agama mayoritas tidak banyak menimbulkan isu keagamaan, tetapi isunya terkait dengan isu ekonomi karena kelompok ini pada umumnya memegang kekuatan ekonomi dibandingkan dengan masyarakat lokal.

$$
\text { Isu agama biasanya }
$$

menyebabkan ada yang terusik oleh aktivitas dan kegaiatan yang dilakukan oleh masingmasing agama, baik yang dilakukan oleh kelompok minoritas maupun oleh kelompok mayoritas. Di sumatera Barat Isu-isu keagamaan itu berkembang tiga tahun ini adalah isu anatara kelompok mayoritas dengan kelompok minoritas Nasrani (Kristen Khatolik-Protestan), isus-isunya terkait dengan;

Murtad

Isu permutadatan ini, dilator belakangi oleh kenyataan ditemukan adanya permutadan dikalangan orang Minang, kemudian isu ini menjadi isu yang terus menerus dikembangkan dan dihembuskan sebagai bentuk perlawananperlawanan atas pemrtadan yang sudah terjadi.

Murtad adalah isu agama yang menjadi isu kebencian bagi kalangan mayoritas yang pindah ke agama minoritas. Berpindahnya agama seorang bersuku Minangkabau ke agama lain menjadi preseden buruk dikalangan masyarakat Minangkabau di Sumatera Barat, isu ini bisa menjadi kebencian yang luar biasa bahkan orang melakukan pindah agama itu bisa mendapatkan hokum adat yang berimbas 
pada kaum dan tidak hanya pada diri orang yang murtad ini.

Isu agama yang terkait dengan murtad belakangan ini di sosia media sangat hangat didiskusikan, mulai dari tanggapan humanis sampai pada tanggapan yang sangat radikal. Dari beberapa catatan yang dipublikasi di situs-situs pribadi dan sampai pada jejering sosial, ditemukan kasus pindah agama dilakukan dikalangan orang Minang, bahkan ada yang sudah menjadi pendeta. Kasus ini menjadi isu agama yang selalu menjadi hangat dibicarakan dan bahkan menjadi trending hot selalu di media sosial. Menjadi isus dan topic yang tidak pernah pudar apalagi kalau terjadi geliat-geliat gerakan keagamaan, selalu menjadi kata kunci dipermurtadan ini. Berkali-kali di berbagai situs dimunculkan kembali, rangorang Minang yang murtad tersebut.

Isu-isu pemurtadan atau lebih dominan dikaitkan dengan isu kristenisasi merupakan isus agama yang merupakan isu yang selalu bermunculan, isu ini menjadi isu yang dilatar belakangi oleh factor sejarah dan factor gerakan-gerakan keagamaan. Faktor sejarah misalnya, ada trauma sejarah yang terjadi misalnya dari kasus pindah agama orang Minang kemudian menjadi pendeta. Realitas ini menjadi fakta yang selalu lekat dalam ingatan masyarakat Minangkabau. Akibat dari itu, ketakutan-ketakutan terhadap keterulangan sejarah ini menjadi hal yang selalu diingatkan dengan cara-cara demikian.

\section{Penyebaran Ajaran Agama}

Selain daripada isu pemutadan, ditemukan juga adanya isu penyebaran ajaran agama ke dalam kelompok beragama, teruatama kedalam kelompok maoyoritas Minangkabau yang beragama Islam. Penyebaran agama bisa dilakaukan melalui kegiatan kegiatan keagamaan dan bisa pula dengan strategi yang bisa meyakinkan orang lain. Beberapa yang dilakukan dalam penyebaran agama ini diantaranya adalah;
Tabel 3

Cara Penyebran Agama Yang Menjadi Isu Keagamaan

\begin{tabular}{|c|c|c|}
\hline No & Bentuk Kegiatan & Isu-Isu \\
\hline 1 & $\begin{array}{l}\text { Translasi Kitab Suci Ke } \\
\text { dalam Bahasa Lokal- } \\
\text { Minang }\end{array}$ & $\begin{array}{l}\text { Pemeluk agama } \\
\text { nasrani, mentraslet } \\
\text { Injil ke dalam bahasa } \\
\text { Minang kemudian } \\
\text { beredar ke di tengah- } \\
\text { tengah masyarakat }\end{array}$ \\
\hline 2 & $\begin{array}{l}\text { Pemakaian symbol- } \\
\text { simbol lokalitas }\end{array}$ & $\begin{array}{l}\text { Perayaan Agama } \\
\text { atau ketika dilakukan } \\
\text { dalam peribadatan }\end{array}$ \\
\hline 3 & $\begin{array}{l}\text { Dakwah-Penyebaran } \\
\text { agama }\end{array}$ & \begin{tabular}{lr}
\multicolumn{3}{l}{ Melakukan } \\
pengajaran agama \\
secara diam-diam \\
atau terang-terangan \\
pada orang yang \\
sudah beragama/ \\
bahkan ada dalam \\
bentuk pemberian \\
material rran \\
seseorang & pada \\
kelompok & atau \\
supaya & merang \\
pindah dalam ajaran \\
agama pemberi.
\end{tabular} \\
\hline 4 & Pendirian rumah ibadah & $\begin{array}{l}\text { Pendirian rumah } \\
\text { ibadah selain rumah } \\
\text { ibadah Islam di } \\
\text { Sumatera Barat } \\
\text { sering menjadi isu } \\
\text { agama. }\end{array}$ \\
\hline 5 & Hiburan & \begin{tabular}{lrr} 
Film & Cinta & Tapi \\
Beda, & pertunjukan \\
seperti & memakai \\
pakaian & \multicolumn{2}{c}{ Adat } \\
Minang ketika ada \\
kebaktian dll.
\end{tabular} \\
\hline
\end{tabular}

Penyebaran agama, merupakan suatu keharusan tetapi penyebaran agama yang dilakukan kepada kelompok masyarakat yang sudah beragama baik itu dilakukan oleh kelompok mayoritas maupun minoritas, maka hal ini akan menjadi isu keagmaan. Untuk menghindari hal ini menjadi isu agama, pemerintah pun telah mengeluarkan misalnya Peraturan Bersama Menteri Agama dan Menteri Dalam Negeri No 9 Tahun 2006 dan Nomor 8 Tahun 2006 tentang Pedoman Pelaksanaan Tugas Kepala Daerah/Wakil Kepal Adaerah Dalam Pemeliharaan Kerukunan Umat Beragama, Pemberdayaan Forum Kerukunan Umat Beragama, Dan Pendirian Rumah Ibadat dan pada tahun 2015 
sudah diajukan pula Rancangan UndangUndang Tentang Kerukunan Umat Beragama.

\section{Pendirian Fasilitas}

Menjadi isu agama lagi di Sumatera Barat adalah isu pendirian fasilitas umum yang dibangun oleh pihak agama minoritas. Hal ini sempat mendapat perlawanan melalui demontrasi dan penolakan dari kelompokkelompok masyarakat. Misalnya terlihat dari penolakan terhadap dibangunnya fasilitas rumah sakit Siloam oleh Lippo Group di Padang, karena Lippo Group merupakan perusahaan yang dikuasi oleh pengaut Nasrani tersebut jadi kehadiran Rumah Sakit tersebut dicurigai sebagai bentuk dari kekuasaan agama Nasrani jika berdiri di kota Padang.

Kehadiran rumah sakit ini mendapat reaksi yang keras, pada hal pemancangan tiangnya sudah dilakukan pada tanggal $10 \mathrm{Mei}$ 2013 dan dilakukan bersama-sama dengan kepala daerah. Namun, akhirnya mendapat tantangan yang luar biasa dari masyarakat Sumatera Barat dan disertai dengan surat pernyataan yang ditanda tangani oleh beberapa petinggi ormas-ormas Islam bahkan oleh calon anggota legislatif yang akan bertanding menghadapi pemilu 2014. Hal ini pun sebagai kesempatan pula oleh calon-calon legislatif untuk menarik simpatisan dengan mengikuti alur psikologis masyarakat.

Selama beberapa hari masa turun kejalan menolak kehadiran Rumah Sakil Siloam tersebut dengan menyuaran berbagai yel-yel, termasuk yek anti kristenisasi. Jadi pembangunan atas sponsor-sponsor dan lebel agama selain dari agama mayoritas di Sumbar berpotensi menjadi isu agama.

\section{RESPON TERHADAP ISU AGAMA}

Respon merupakan perasaan, aktivitas, perbuatan atau perkataan yang muncul dalam menentang atau menanggapi atas munculnya isu-isu agama yang muncul di Sumatera Barat. Respon tersebut tidak hanya terlihat dari gerakan realitas tertapi juga dilakukan melalui ide dalam bentuk tulisan-tulisan. Di Sumatera Barat respon-respon itu, muncul dalam bentuk sikap dan penolakan yang disampaikan dalam pembicaraan atau dalam bentuk tulisan atau pernyataan.

Respon ini pada umumnya biasanya berbentuk penolakan atau perlawanan, karena biasanya isu agama sesuatu yang dianggap berbeda dengan kehendak mayoritas. Respon juga bisa dimaknai sebagai bentuk daripada perlawanan-perlawanan baik secara radikal maupun secara ide. Namun, isu agama di tengah-tengah mayoritas adalah berbetuk penolakan ketidak lumrahan yang dialami oleh mayoritas terhadap isu agama minoritas. Beberapa bentuk respon yang muncul terkait dengan isu agama diantaranya adalah;

Demontarasi

Penolakan melalui demontrasi, selama tahun 2012-2014 paling tingi da sering dilakukan adalah terlihat pada saat adanya penolakan terhadap pendirian rumah sakit Siloam di kota Padang. Beberapa elemen masyarakat bergabung turun ke jalan dan menyuaran penolakan dan anti terhadap pendirian rumah sakit yang dicurigai sebagai bentuk proses kristenisasi di Sumatera Barat. Penolakan ini, berupa bentuk ketidaknyamanan masyarakat mayoritas dengan kehadiran fasilitas-fasilitas yang dibangun dengan kepunyaan bahkan embelembel agama selain dari agama mayoritas masyarakat.

Dalam beberapa kali demontrasi yang dilakukan dalam penolakan pendirian rumah sakit Siloam tersebut, terlihat ada penolakan terang-terangan dan sekligus menybut dengan terang-terangan bahwa proyek tersebut adalah proyek kristenisasi. Elemen-elemen yang menamakan atas nama masyarakat Minangkabau tersebut menuntut supaya proyek rumah sakit itu dihentikan dan tidak dibenarkan berdiri di Sumatera Barat. Malahan ada statemen yang menyatkan bagi siapa yang tidak mendukung gerakan pencegahan berdirinya mega proyek siloam tersebut 
dianggap memberikan kemduratan bagi Sumatera Barat, ungkapan ini misalnya diungkapkan oleh ketua ormas Paga Nagari Ibnu Agil D Ghani ${ }^{7}$

Pada tahun 2013 dua isu itu menjadi perhatian khusus dan paling banyak mendapat respon masyarakat dan dilakukan dengan penolakan demontrasi oleh kalangan masyarakat yang bergabung dengan elemenelemen dan ormas-ormasi Islam. Sedangkan dilain pihak ada keberadaan-keberadaan lain tidak mendapat perhatian penolakan seperti dua hal ini. Menurut catatan Noobaini pada hal masih banyak ajaran-ajaran dan aliranaliran keagamaan yang berkembang di Sumbar sampai tahun 2012, namun hal itu tidak banyak diketahui dan bahkan penentangannya tidak sekuat dengan masalah kristenisasi seperti di atas. ${ }^{8}$

Isu agama dengan Kristenisasi nampaknya lebih diperhatikan dari pada isu-isu agama yang lainnya, sementara isu-isu tentang aliran dan agama yang lainnya bahkan sampai tahun 2012 masih berkembang di Sumatera Barat namun tidak mendapat tantangan seperti yang dilakukan untuk isu kristeniasi. Ada beberapa hal yang kondisi yang demikian itu terjadi sehingga isu kristenisasi menjadi musuh yang harus diberantas, (1) dari segi pergerakan diantara gerakan agama-agama lainnya gerakan kristeniasi sangat cepat dan terlihat langsung dalam realitas sedangkan isu aliran dan agama lain tidak bergiti membangun efek realitas yang luas. (2) Dari segi jumlah pengikut agama ini dibandingkan dari aliran-aliran dan agama yang lainnya jumlahnya cukup signifikan setelah jumlah penganut Islam di Sumatera Barat, jadi ada rasa psikologis bagi kelompok mayoritas gerakan agama ini akan menindih keberadaan mayoritas dengan ajaran dan teologis yang sudah mengakar.

7 New Tribun, Survei Elsam Kebebasan Beragama di Sumatera Barat Terburuk, 4 Juni 2013.

8 Silfia Hanani, Menggali Interelasi Sosiologi dengan Agama, (Bandung: Humaniora, 2012), 34

\section{Sloganisasi dan Antiisasi}

Bentuk-bentuk penolakan terhadap isu agama yang lain lagi adalah, melalui sloganslogan yang disampiakan oleh elite-elite atau kelompok ormas-ormas dalam berbagai kesempatan. Slogan-slogan itu baik dalam bentuk tertulis maupun dalam bentuk ungkapan yang disampaikan dalam berbagai kesempatan, sehingga isu-isu agama terutama tentang isu kristenisasi harus ditangkal dan tidak boleh diberi ruang gerak.

Diskusi-diskusi dan slogan-slogan anti dan tolak kristenisasi ini sangat popular dan bahkan meningkat intenstas pada saat akan dididirkannya Rumah Sakit Siloam di Padang. Namun, setelah tujuan tercapai diskusi-diskusi dan sloganisasi dan antiisasi seperti itu hilang dan tidak ditemukan lagi. Namun, ketika menghadapi Pilkada 2015 ini, permasalahan itu dijadikan isu. Terutama isu untuk menohon daripada salah satu calon pasangan GubernurWakil Gubernur Sumbar yang ketika itu disebut-sebut sebagai pemberi izin kehadiran rumah sakit yang diisukan sebagai proyek kristenisasi tersebut.

Penolakan juga pernah dilakukan melalui keputusan, seperti yang terjadi di Payakumbuh penolakan terhadap berdirinya rumah ibadah Vihara, ponalakan ini sebagaimana dikemukakan di media yang sama dengan situs di atas, dengan ungkapan statemen sebagai berikut "protes keras dari warga kelurahan Nunang kecamatan Payakumbuh Barat atas adanya rencana pembangunan Vihara Budha Metta di kawasan jalan Luhak Limapuluh Kota. Surat keberatan dan pernyataan sikap penolakan dengan nomor 01/LPM/NN-PBR/II-2012 tertanggal 2 Februari 2012 yang dialamatkan ke walikota dan DPRD Payakumbuh oleh lembaga pemberdayaan masyarakat kelurahan Lunang yang juga ditanda tangani oleh ketua RT, tokoh masyarakat dan beberapa lainnya. Akibatnya, rencana pembangunan Vihara Budha Metta di kawasan itupun gagal. Pemerintah setempat juga menghentikan 
sementara waktu rencana tersebut dengan berbagai alasan"

Namun, belakangan pada tanggal 22 November 2015 di Padang digelar Parade Salib, dengan berkeliling disekitar Kota Padang, namun parade ini tidak mendapat kecaman seperti kecaman kehadiran rumah sakit Siloam. Hanya muncul beberapa stateman saja dengan nada yang mengecam, seperti bunyi kecamannya "Kahadiran Parade Salib di Padang, Menciderai Adaik Basandi Syarak, Syarak Basandi Kitabullah pernyataan ini salah satunya dikemukakan oleh Maad Achin Ketua Umum Gerakan Muslimin Minangkabau sebagaimana diberitakan di media Minangkabau News tanggal 27 November 2015.

Respon negatif dan penolakan terhadap kegiatan ini ternyata hampit tiada, bahkan MUI pun tidak memberikan komentar atau statemen. Dari realitas ini dapat diperoleh bahwa masyarakat Minang, memiliki tradisi kultural ada masa seperti dicerminkan oleh pepatah sakali suruik, sakali malangkah artinya ada negosiasi yang dibangun. Mungkin hal ini tidak mendapatkan pertentangan yang luas, karena kegiatan ini sifatnya tidak permanen dan bahagian dari ritual agama yang tidak mempunyai imbas yang jauh terhadap ekonomi, sosial dan politik. Sedangkan keberadaan siloam mempunyai imbas yang komplek dari segi ekonomi dikuatirkan akan mematikan atau meminggirkan ekonomi lokal, sosial akan berdampak pada citra luas terhadap kekalahan budaya Minang yang penuh dengan simbolisasi Islam dan seterusnya.

\section{BENTUK-BENTUK PENYELESAIAN ISU KEAGAMAAN}

Isu-isu keagamaan di Sumatera Barat pada prinsipnya muncul dari tanggapan mayoritas terhadap minoritas. Mayoritas, mempunyai tream yang sudah mengakar dalam perpspektif sejarah dan berusaha menjaga teream itu dengan sikap ekslusifisme. Tidak bisa menerima secara utuh, baik secara psikologis maupun secara sisologis idiologis minoritas yang bertentangan dengan teologis mayoritas. Apalagi tream miniritas itu, dibuka dalam isu global seperti isu kritenisasi dengan sepak terjanganya dalam penyebaran agama yang dibungkus dengan berbagai isu-isu, maka hal ini menjadi satu dampak psikologis yang membuat mayoritas Minangkabau dapat menerima isu-isu kristenisasi tersebut.

Namun, isu-isu tersebut masih banyak diselesaikan dalam bentu inverstigasiinvestegasi yang dilakukan oleh beberapa organisasi yang terlobat dengan proses harmonisasi, seperti investigasi yang dilakukan oleh LBH padang dan Komnas HAM. Investigasi ini tidak melahirkan bentuk penyelesaian-penyelesaian yang signifikan sehingga yang terjadi adalah konflik "imanjiner". Konflik ini secara frontal tidak wujud tetapi secara psikologis atau silent conflict terlihat.

Silent Conflict bisa berlanjut dalam bentuk tindakan-tindakan, baik maupun dalam bentuk tindakan yang memicu lahirnya disharmonis. Misalnya, munculnya penolakanpenolakan terhadap kehadiran rumah ibadah, kehadiran pemakaman selain daripada kelompok mayoritas. Penolakan-penolakan ini muncul secara terus meneru karena silent conflict ini tidak selesaikan sampai pada akar permasalahannya.

Penyelesaian yang dilakukan tentang isu-isu keagamaan di Sumatera Barat mulai dari bentuk radikalisme sampai pada negosaisi. Radikalisme dapat dilihat dari proses penyelesaian seseorang bersuku Minangkabau di buang sepanjang adat dan diusir dari kampung halaman karena pindah agama dari agama Islam kepada agama selain dari pada Islam. Peristiwa ini dapat dilihat dari pembuangan sepanjang adat yang dilakukan oleh masyarakat terhadap Yunuardi Koto di Lubuk Basung. Lembaga Kerapatan Adat Alam Minangkabau (LKAAM) sebagai organisasi tertinggi di Lubuk Basung sudah menyatakan Yanuardi Koto bukan lagi orang 
kampung halaman di daerah tersebut, karena yang bersangkutan pindah agama kepada agama yang lainnya, bahkan sekarang yang bersangkutan menjadi pendeta dalam agama Nasrani.

Di buang sepanjang adat artinya adalah tidak lagi diakui sebagai orang yang memiliki suku Minangkabau. Harus keluar dari suku terebut, bahkan Yanuardi Koto harus meninggalkan nama Koto di belakang namanya, karena Koto itu merupakan salah satu suku dalam masyarakat Minangkabau. Jika dibuang sepanjang adat maka yang bersangkutan tidak diperbolehkan ke kampung halaman, yang bersangkutan tidak berhak mendapatkan harta pusaka, gelar adat bahkan untuk menetap di kampung halaman.

Negosiasi dan mediasi juga sering dilakukan untuk menyelasiakan isu dan konflika agama, misalnya adanya pelarangan terhadap pendirian rumah ibadah pada satu kawasan maka untuk menjembatani hal ini pemerintah harus melakukan negosiasi, pemerintah harus menjadi mediasi dengan mencarikan solusi sehingga konflik beragama tersebut tidak menjadi konflik horizontal. Hal ini dapat dilihat dari beberapa kasus dimana tidak diperbolehkannya berdirinya rumah ibadah non Islam oleh masyarakat pemerintah memediasi dimana masyarakat yang tidak memiliki rumah ibadah itu memfasilirasinya untuk pergi beribadah rumah ibadah yang terdekat dengan lokali keberadaanya. Misalnya, orang Tanah Datar difasilitasi beribadah keluar daerah atau didatangkan pendeta dengan dipinjamkan gedung tertentu. Hal serupa juga dapat dilihat dari warga Kristen dari semua aliran tinggal dikawasan Muaro Sijunjung. Karena tidak ada fasilitas rumah ibadah, jika mereka hendak melakukan kegiataan keagamaan maka harus pergi ke daerah Sawahlunto dengan jarak kurang lebih $25 \mathrm{Km}$. Selanjutnya dari beberapa pernayataan Firdaus Kasubag Pelayanan Pengaduan Komnas Ham Padang menyatakan, bahkan dalam beberapa konflik keagamaan pemerintah di Sumatera
Barat juga tidak bisa berbuat banyak karena isu agama di Sumatera Barat sangat sensitif. Bahkan di lembaga pemerintah pun terjadi penolakan-penolakan jika ada pimimpin dari lembaga itu beragama selain daripada Islam seperti yang terjadi di salah satu kejaksaan dimana seorang jaksa dipindah tugaskan ke Kejaksanaan Negeri Pasaman Barat untuk posisi sebagai kepala bagian ditolak keras oleh masyarakat karena ia diketahui bukan berasal dari agama mayoritas.

Bentuk penyelesaian selanjutnya adalah, toleransi dalam memahami mayoritas dari minorias di ruang publik. Di Ruang publik minoritas dan mayoritas dapat Nampak bersatu, karena adanya pemahaman dari masing-masing tersebut, misalnya dengan adanya aturan-aturan di sekolah di Sumatera Barat pakai jilbab maka untuk merasakan dan mendapatkan rasa aman, maka minoritas mengikuti atribut pakain mayoritas tersebut. Perlindungan rasa aman seperti ini pada dasarnya juga sudah dibuktikan oleh masyarakat etnis China di Sumatera Barat. Etnis ini sebagai kelompok minoritas bisa mengendalikan egosentrisme dengan melakukan pengayatan ke publik setidaknya dapat dilihat daripada bahasa yang digunakannya, tidak ekslusif tetapi inklusif bisa berbahasa masyarakat mayoritas. Bahasa tersebut akhirnya menjadikan mereka secara psikologis menjadi bahagian dari mayorias, bisa akrab dan diterima ${ }^{9}$

Penyelesaian-penyelesaian isu agama juga dilakukan dengan dialog antar umat beragama. Dialog antar umat beragam baru bisa difasilirasi oleh pihak-pihak yang terkait, seperti Forum Komunikasi Antar Umat Beragama (FKUB). Dialog yang melibatkan elite-elite dari masing-masing agama. Seperti pernah dilakukan diakhir tahun 2014 dimana

9 Silfia Hanani, "Model Konstruksi Toleransi Antar Umat Beragama Pemeluk Agama Mayoritas dan Minoritas Pada Masyarakat Perkotaan Kota Padang Panjang Di Sumatera Barat". (Salatiga: Renai Percik, 2011), 156-167. 
semua lintas agama yang terangkum berdialog dalam menyelesaikan dan mengatasi isu dan konflik agama yang terjadi di Sumatera Barat. Namun ketika itu, lebih banyak membuat antisipatif terhadap pelaksanaan pemilu supaya tidak ditunggangi dengan isu agama.

Dialog pada dasar membuat kesehapafan dalam membangun keharmonian antara umat beragama sehingga isu-isu agama yangmuncul tidak mengusik kehidupan bersama. Namun, jika dilihat dari kasus 2013 tentang penolakan terhadap kehadiran Rumah Sakit Siloam merupakan sebuah kahrusan yang dilakukan oleh pemerintah untuk menghentikan kegiatan tersebut, mengingat ekspitasi penolakan yang dilakukan oleh masyarakat terhadap kehadiran fasilitas tersebut.

Dalam konteks ini, dapat difahami apa yang dimaksud oleh Gandhi terkait dengan kemajemukan, dimana perbedaan-perbedaan yang ada bisa hidup dengan damai apabila ada sikap toleransi, namun esensial toleransi ini masih dimaknai dengan cara keterpaksaan bukan atas dasar kesadaran, yang terlihat adalah secara factual damai namun secara psikologis mikro bergejolak, setidaknya dapat dilihat apa yang terjadi di ruang social media public yang berdisikusi penuh dengan kebencian-kebencian dan penolakanpenolakan. Damai di permukaan namun tidak damai di ruangan publik media social. Di ruagan itu saling hujat menghujat, saling tuding dan cacian-cacian.

Hal ini dapat dilihat dari kasuskasus yang berkembang tentang pendirian rumah sakit Siloam di Padang dimana sampai saat ini masih saja menjadi diskusi di ruangan publik media social dengan isu-isu kritenisasi. Diskusi tersebut bisa dilihat dengan terbuka oleh semua orang yang mengkasesnya. Keterbukaan di ruangan publik melalui kebebasan dimedia social, ternyata sebagai sarana akses untuk bisa damai di dunia realitas, karena dari segi psikologis diskusi di dunia maya membangun keterbebasan psikologis orang bebas komentar setelah bebas lupa aksi dan tindakan kekerasan di realitas.

Kemudian diskusi itu juga membuat pihak-pihak minoritas dapat bersikap hati-hati dalam bertindak dan bersikap terhadap kondisi mayoritas. Ada sikap memaknai kehendak dominasi, sehingga secara temporer bisa menghentikannya seperti kasus pendirian rumah sakit Siloam, dengan besarnya tekanan di ruangan publik social media akhirnya bisa dilakukuan berhati-hatian sehingga dihentikan kegiatan pendirian tersebut.

\section{KESIMPULAN}

Intoleransi beragama di Sumatera Barat pada tahun 2014-2015 mengalami peningkatan yang dipengaruhi oleh penilakanpenolakan fasilitas yang akan dibangun oleh investor yang berbeda agama dengan mayoritas agama masyarakat. Pada masa ini sudah isu-isu agama sudah dibangun oleh masyarakat, dimana masyarakat tidak mudah menerima agama Islam yang baru saja dikembangkan oleh pedangang Arab yang terdampar itu. Pada saat itu agama Budha dan Hindu masih kuat dan mayoriti dipraktekkan oleh masyarakat setempat. Isu agama biasanya menyebabkan ada yang terusik oleh aktivitas dan kegaiatan yang dilakukan oleh masingmasing agama, baik yang dilakukan oleh kelompok minoritas maupun oleh kelompok mayoritas.

Di sumatera Barat Isu-isu keagamaan itu berkembang tiga tahun ini adalah isu anatara kelompok mayoritas dengan kelompok minoritas Nasrani (Kristen KhatolikProtestan), isus-isunya terkait dengan murtad, penyebaran agama, pendirian fasilitas. Pada tahun 2013 dua isu itu menjadi perhatian khusus dan paling banyak mendapat respon masyarakat dan dilakukan dengan penolakan demontrasi oleh kalangan masyarakat yang bergabung dengan elemen-elemen dan ormasormasi Islam. Sedangkan dilain pihak ada keberadaan-keberadaan lain tidak mendapat perhatian penolakan. 


\section{BIBLIOGRAFI}

Abdullah, Amin, "Perspektif Analitis dalam Studi Keragaman Agama. Mencari Bentuk Baru Metode Studi Agama. Harmoni Kehidupan Beragama Problem dan Praktik Pendidikan. Yogyakarta: Oasis Publisher, 2004.

Al-Amin, Imam Maulana Abdul Munaf, Mubalighul Islam, Padang: Bagian Urusan Kebudayaan Sumatera Barat, 1883.

BPS Sumatera Barat. 2012. Data Jumlah Penduduk Sumatera Barat Menurut Kabupaten dan Kota.

Djokosurjo, dkk., Agama dan Perubahan Sosial, Studi Antara Hubungan Islam, Masyarakat dan Struktur Sosial Politik Indonesia, Yogyakarta: LPKSM, 2001.

Goddard, Hugh, Enam Dimensi Hubungan Islam Kristens, Harmoni Kebidupan Beragama Problem dan Praktik Pendidikan, Yogyakarta: Oasis Publisher, 2004.

Hantington P. S., Benturan Antar Peradaban Dan Masa Depan Politik Dunia, Yogyakarta: Qalam, 2000.

Hanani, Silfia, Menggali Interelasi Sosiologi dengan Agama, Bandung: Humaniora, 2012.

Hanani, Silfia. "Model Konstruksi Toleransi Antar Umat Beragama Pemeluk Agama Mayoritas dan Minoritas Pada Masyarakat Perkotaan Kota Padang Panjang Di Sumatera Barat", Renai, Salatiga: Percik, 2011.

Hardi, Andri. "Interfaith dialogue Dalam Konteks Hubungan Internasional", Tabloid Diploma, Jakarta: Kementerian Luar Negeri Indonesia, 2010.

Haryanto, Sindung, Spektrum Teori Sosial dari Kalsik Hingga Postmodern, Yogyakarta: Arruz, 2012.

Kementerian Pendidikan Nasional Badan Penelitian dan Pengembangan Pusat Kurikulum, Bahan Pelatihan Penguatan Metodologi Pembelajaran Berdasarkan Nilai-nilai Budaya Untuk Membentuk Daya Saing dan Karakter Bangsa, Jakarta, 2010.

Muhaemin, Enjang, and Irfan Sanusi, "Intoleransi Keagamaan dalam Framing Surat Kabar Kompas." Communicatus: Jurnal Ilmu Komunikasi, 3.1, 2019.

Nazir, Moh., Metode Penelitian, Jakarta: Ghalia Indonesia, 2012.

Padang Ekspres, 27 Maret 2013. “Kab. 50 Kota 117 Wanita Hamil di Luar Nikah”

Parekh, Bikhu, Retbinking Multiculturalism: Keberagaman Budaya dan Teori Politik, Yogyakarta: Kanisius, 2008.

Ritzer, G. \& Goodman, J. D., Modern Sociological Theory, USA: McGraw-Hill, 2005.

Sugiyono, Metode Penelitian Pendekatan Kualitatif dan Kuantitatif, Bandung: Alabeta, 2010.

Suseno, Franz Magnus, "Interfaith Dialogue Jendela Untuk Menampakkan Keberhasilan Indonesia Dalam membangun Kerukunan dan Toleranasi”, Tabloid Diploma, Jakarta: Kementerian Luar Negeri Indonesia, 2010

, "Kerukunan Agama dalam Keberagamaan Agama Kasus di Indonesia", Harmoni Kehidupan Beragama Problem dan Praktik Pendidikan, Yogyakarta: Oasis Publisher, 2004.

Titaley, Jhon., "Beberapa Model Keragaman di Asia: Keunikan Kehidupan Beragama di Indonesia", Harmoni Kebidupan Beragama Problem dan Praktik Pendidikan, Yogyakarta. Oasis Publisher, 2004. 
Toha, Soherman, dkk., Laporan Hasil Penelitian Eksistensi Surat Keputusan Bersama Dalam Menyelesaikan Konflik Antar dan Intern Agama, Jakarta: Badan Pembina Hukum Nasional Kementerian Hukum dan HAM, 2011.

New Tribun, Survei Elsam Kebebasan Beragama di Sumatera Barat terburuk. 4 Juni 2013.

Ting-Toomey, Stella, Communicating Across Culture, New York: The Guildford Press, 1999. 